\title{
HUKUM ADAT LONTARA
}

\author{
Anugrah \\ Fakultas Hukum, Institut IImu Sosial Dan Bisnis Andi Sapada \\ Email:Kmstinto598@gmail.com
}

\begin{abstract}
Abstrak
Bangsa Indonesia merupakan bangsa yang beragam karena terdiri dari berbagai suku bangsa, adat istiadat,bahasa daerah, dan agama yang berbeda. Keanekaragaman ada di berbagai daerah, yang tersebar dari Sabang sampai Merauke. Indonesia merupakan negara yang melahirkan berbagai suku bangsa dan dari suku-suku inilah yang menjadikan ciri khas atau keunikan masing-masing suku di Indonesia. Bugis adalah salah satu suku besar di Sulawesi Selatan. Budaya Bugis-Makassar adalah budaya suku Bugis Makassar yang mendiami semenanjung selatan pulau Sulawesi. Suku Bugis sebagai salah satu suku terbesar di Sulawesi Selatan memiliki budaya tersendiri nilai. Ada tiga bentuk kebudayaan, yaitu sistem budaya, sistem sosial dan berwujud hasil budaya yang saling terkait dan berhubungan dengan struktur budaya. Itu Struktur budaya yang dimaksud antara lain adalah sistem politik yang mengatur hubungan antar anggota masyarakat, terutama yang berkaitan dengan pembagian tugas dan pelaksanaan kekuasaan. Kekuasaan kerajaan yang dipegang oleh orang Bugis pada masa lalu berbentuk monarki atau kerajaan
\end{abstract}

Kata Kunci : Hukum Adat, Suku Bugis

\section{Latar Belakang}

Kebudayaan merupakan persoalan yang sangat komplek Kebudayaan sebagai bagian dari kehidupan, cenderung berbeda antara satu suku dengan suku lainnya, khususnya di Indonesia. Masyarakat Indonesia dan luas, misalnya kebudayaan yang berkaitan dengan cara manusia hidup, adat istiadat dan tata krama. Yang heterogen juga adat istiadat dan kebiasaannya yang berbeda dan masih dipertahankan sampai saat ini, termasuk adat perkawinan.Masyarakat Bugis merupakan salah satu suku yang masih mempertahankan budaya dan adat istiadatnya di Indonesia. Suku Bugis yang tergolong ke dalam suku-suku Melayu Deutero, berasal dari kata To Ugi, yang berarti orang Bugis Penamaan "ugi" merujuk pada raja pertama kerajaan Cina yang terdapat di Pammana, Kabupaten Wajo saat ini, yaitu La Sattumpugi. Mereka menjuluki dirinya sebagai ToUgi atau orang-orang atau pengikut dari La Sattumpugi. Dalam perkembangannya, komunitas ini berkembang dan membentuk beberapa kerajaan lain. Masyarakat Bugis ini 
kemudian mengembangkan kebudayaan, bahasa, aksara Lontara dan pemerintahan mereka sendiri. Beberapa kerajaan Bugis klasik dan besar antara lain Luwu, Bone, Wajo, Soppeng, Suppa dan Sawitto (Kabupaten Pinrang), Sidenreng dan Rappang.

Suku Bugis yang menyebar dibeberapa Kabupatenvmemiliki adat istiadat yang masih dipertahankan keberadaanya. Dalam masyarakat Bugis, hubungan kekerabatan merupakan aspek utama,baik dinilai penting oleh anggotanya maupun fungsinya sebagai suatu struktur dasar dalam suatu tatanan masyarakat. Pengetahuan mendalam tentang prinsip-prinsip kekerabatan sangat penting bagi orang Bugis untuk membentuk tatanan social mereka.Aspek kekerabatan tersebut termasuk perkawinan, karena dinggap sebagai pengatur kelakuan manusia yang bersangkut paut dengan seksnya dan kehidupan rumah tangganya. Selain itu perkawinan juga berfungsi untuk mengatur ketentuan akan harta gengsi sosial dan lebih penting lagi adalah memelihara hubungan kekerabatan. Suku Bugis khususnya Bugis Bone, memaknai perkawinan berarti siala atau mengambil satu sama lain, jadi perkawinan merupakan ikatan timbal balik. Pihak-pihak yang terlibat berasal dari strata sosial yang berbeda, namun setelah mereka menikah mereka akan menjadi mitra dalam menjalani kehidupannya.

Bangsa Indonesia merupakan bangsa yang majemuk karena terdiri atas berbagai suku bangsa, adat istiadat, bahasa daerah, serta agama yang berbedabeda. Keanekaragaman terdapat di berbagai wilayah yang tersebar dari Sabang sampai Merauke. Indonesia adalah negara yang melahirkan beragam suku bangsa dan dari suku-suku itulah yang membuat adanya ciri khas atau keunikan dari setiap suku yang berada di Indonesia.

Hukum adat adalah aturan yang tidak tertulis dan merupakan pedoman untuk sebagian besar orang-orang Indonesia dan dipertahankan dalam pegaulan hidup seharihari baik di kota maupun di desa. Hukum adat adalah hukum yang hidup karena ia menjalankan perasaan hukum masyarakat secara nyata. Hal ini dimungkinkan karena hukum adat tersebut berurat dan berakar pada kebudayaan masyarakat. Oleh karena itu, keberadaan hukum adat sebagai salah satu sumber pembentukan hukum nasional tetap memiliki kedudukan yang sangat penting. Dalam kerangka pembangunan hukum nasional, hukum adat yang merupakan hukum yang hidup (living law) adalah salah satu unsur yang diakui urgensinya.

Bugis adalah salah satu etnik besar di Sulawesi Selatan. Kebudayaan BugisMakassar adalah kebudayaan dari suku bangsa Bugis Makassar yang mendiami jazirah selatan pulau Sulawesi. Suku Bugis sebagai salah satu suku terbesar di Sulawesi Selatan memiliki nilai kebudayaan tersendiri. Ada tiga wujud kebudayaan, yaitu sistem budaya, sistem sosial dan hasil nyata budaya yang satu sama lain berhubungan secara timbal balik dan saling berhubungan dengan struktur kebudayaan. Struktur kebudayaan yang dimaksud antara lain adalah sistem politik yang mengatur hubungan antara anggota masyarakat terutama yang barkaitan dengan pembagian tugas dan penyelenggaraan kekuasaan. Kekuasaan kerajaan 
yang dianut oleh bangsa Bugis zaman dulu adalah berbentuk monarchi atau kerajaan.

Kesemua wilayah hukum berdialeg Bugis terdapat pula eks kerajaan besar lain yang memiliki ciri khas kebudayaannya, bahkan dapat diklasifikasikan sebagai kerajaan imperium yang pernah memegang hegemoni. Kerajaan yang dimaksud adalah tellumpoccoe, yakni Bone, Luwu dan Gowa. Kerajaan-kerajaan yang dimaksud sering menaklukkan kerajaan lain yang lebih kecil lainnya. Tampaknya, bocco (kerajaan besar) inilah yang menjadi prototype imperium yang pada gilirannya mengakibatkan terjadinya perebutan hegemoni. Bone, Luwu dan Gowa adalah kerajaan setara, namun dalam proses pertumbuhannya terdapat beberapa perbedaan sistem birokrasi dan pemerintahan. Sistem yang dipakai itu, meskipun tidak cocok lagi dengan kondisi sekarang, namun tidak begitu saja dibuang, karena tidak ada salahnya apabila masa lampau itu dipelajari, dikaji terutama pada puncakpuncak kebudayaan daerah yang membawa tingkat kejayaan, kebesaran dan keagungannya.

\section{PEMBAHASAN}

Kebudayaan Sulawesi selatan di warnai oleh tiga suku bangsa, yaitu suku Bugis, Makassar, Toraja. Suku yang terbesar jumlahnya adalah Bugis, menempati sebagian besar jazirah Sulawesi selatan. Kebudayaan suku-suku bangsa itu terdapat persamaan wujud, bentuk dan pola namun perbedaan tidak dapat dimungkiri. Perbedaan lingkungan, membawa perbedaan gaya hidup dan mungkin pada kepribadian. Keadaan tanah, air, gunung dan iklim turut membentuk gaya hidup penduduk. Mereka menyelenggarakan penghidupannya, membuat alat-alat mata pencaharian, maka faktor keadaan alam turut memberi bentuk dan wujud. Pergumulan hidup hasil kontak dengan alam, mereka kembangkan kebiasan dan cara mengolah alam untuk memenuhi kebutuhan dan mempertahankan kelompok. Kebiasaan dan cara yang senantiasa dilakukan, baik secara individual maupun berkelompok, lambat laun akan terbentuk pola kebiasaan yang mengarah pada pengorganisasian kegiatan untuk suatu tujuan tertentu.

Keadaan alam mengharap manusia menyesuaikan hidup, kebudayaan berupa upacara minta hujan, penolak bahaya gempa dan banjir, sangat besar Artinya bagi kehidupan petani. Keadaan alam tidak saja memberi pembatasan terhadap kelangsungan hidup manusia dan kebudayaannya, akan menyediakan berbagai macam bahan yang dapat di manfaatkan oleh manusia. Manusia adalah makhluk berakal, betapa pun sederhananya kebudayaannya, mereka sudah merubah alamnya menurut cara dan kemampuan yang di miliki.

Perubahan alam oleh tiap suku bangsa, apakah mereka disebut bangsa sedehana atau bangsa modern, perbedaannya terletak pada tingkat kemajuan dan bukan pada jenis kemajuan yang telah dicapai. Suku bangsa yang masih sederhana, mereka mengolah alam dengan cara dan teknik sendiri mereka mempunyai alat-alat 
pencaharian sendiri, alatalat untuk menentang kemauan alam dan mengolah alam sedemikian rupa untuk memenuhi kebutuhan hidup dengan catatan bahwa tidaklah kemampuan itu selalu di serahkan kepada kekuatan alam. Disini tidak bermaksud memihak pada salah satu metode berfikir "dereminisme geografik" dan penentangnya, akan tetapi persoalan diletakkan pada masalah, bagaimana posisi manusia dalam berintraksi dengan lingkungan alamiah dan lingkungan manusiawi sebagai suatu kesatuan komunitas. Hal ini berarti, bahwa perkembangan kebudayaan manusia tidak saja di tentukan oleh alamnya, tetapi juga ditentukan oleh kelompoknya.

Bugis merupakan kebudayaan tertua di Nusantara. Bugis memiliki nilai-nilai yang ingin disampaikan. Ada beberapa nilai-nilai budaya yang terkenal dalam masyarakat Bugis, yakni kejujuran (alempureng), kecendikiaan (amaccang), kepatutan (asitinajang), keteguhan (agettengeng), usaha (reso), dan malu. Lontara dapat diartikan tulisan atau buku. Sebagai tulisan ia berbentuk segi empat (belah ketupat). Buku yang dimaksud adalah buku yang di dalamnya memuat hasil intelektual leluhur Bugis-Makassar.

Perkawinan adat dalam suku Bugis disebut pa"bungtingan. Upacara perkawinan (pa"bungtingan) banyak dipengaruhi oleh ritual-ritual sakral dengan tujuan agar perkawinan berjalan dengan lancar dan pernikahannya mendapat berkah dari Tuhan. Sebelum prosesi pa"bungtingan dilakukan, terdapat beberapa tahap yang harus dilalui oleh calon mempelai laki-laki. Diantaranya adalah A"jagangjagang/Ma"manu-manu, A"suro/Massuro, dan Appa"nasa/Patenre Ada.A"jagangjagang adalah penyelidikan secara diamdiam oleh pihak calon mempelai pria untuk mengetahui latar belakang pihak calon mempelai wanita. A"suro/massuro adalah acara pinangan secara resmi pihak calon mempelai pria kepada calon mempelai wanita. Appa"nasa yaitu menentukan hari pernikahan. Selain penentuan hari perkawinan, juga disepakati besarnya mas kawin dan uang belanja. Uang belanja dalam suku Bugis biasa disebut Uang Panai".

Lontara merupakan karya asli masyarakat Bugis. Bagi masyarakat Bugis, lontara dapat berfungsi sebagai; (1) lambang jati diri, (2) lambang kebanggaan, dan (3) sarana pendukung budaya daerah. Lontara tersebut dinyatakan sebagai lambang jati diri karena memuat berbagai nilai budaya yang menjadi ciri khas masyarakat Bugis; Lontara dinyatakan sebagai lambang kebanggaan karena sikap yang mendorong sekelompok orang menjadikan Lontara sebagai lambang identitasnya, dan sekaligus dapat membedakannya dengan kelompok orang lain; dan Lontara dinyatakan sebagai sarana pendukung budaya daerah karena mengandung informasi kultural untuk membangun tatanan sosial dalam rangka memperkukuh budaya nasional. Karena pentingnya fungsi yang diemban tersebut, Lontara tetap dipelihara dan dilestarikan oleh masyarakat Bugis. Secara sadar atau tidak, tampaknya perlakuan masyarakat Bugis terhadap Lontara, sejalan dengan amanat UUD 1945 pasal 32, menyatakan bahwa unsur budaya bangsa itu akan tetap dihormati dan dipelihara oleh negara. 
Naskah Lontara sebagai dokumen tentang peristiwa yang berkaitan dengan orang Bugis pada masa lalu. Oleh karena itu, naskah Lontara dapat dipandang sebagai sumber informasi mengenai sejarah, sosial, dan budaya, serta peranserta suku Bugis dalam kehidupan masyarakat di daerah Sulawesi. Dalam kaitan ini, naskah lontara dapat dipandang sebagai produk budaya suku Bugis. Di samping itu, Lontara dapat dipandang sebagai realitas penggunaan bahasa yang mencerminkan perilaku dan pandangan hidup masyarakatnya. Lontara tersebut digunakan untuk mengungkapkan berbagai macam bentuk ritual, doa, dan ceritra. Dengan demikian, dapat dinyatakan bahwa naskah Lontara dipandang sebagai bahasa dari indeks budaya dan dipersepsikan sebagai pengungkapan cara berpikir, penataan pengalaman penulisnya, dan simbol budaya yang menunjukkan identitas budaya etnis.

Aksara Lontara adalah aksara tradisional masyarakat Sulawesi Selatan yang umumnya digunakan oleh suku Bugis, Makassar, dan Mandar. Aksara kuno ini kemudian terus berevolusi seiring perkembangan zaman, hingga akhirnya menjadi Aksara Lontara yang dikenal saat ini. Bentuk aksara ini memiliki nilai budaya yang sangat mendalam bagi masyarakat suku Bugis-Makassar, yaitu bentuknya yang berasal dari filosofi "Sulapa Eppa" yang berarti Empat Sisi api, air, tanah, dan angin, susunan semesta kepercayaan mistis Suku Bugis klasik.

Penggunaan aksara ini digunakan oleh suku Bugis yang secara geografis tersebar di hampir seluruh penjuru Sulawesi Selatan. Dalam masyarakat tradisional di Sulawesi Selatan adat istiadat Suku Bugis-Makassar sangat mendominasi sehingga Aksara Lontara digunakan dalam penulisan dokumen aturan

pemerintahan, kemasyarakatan, dan hingga beberapa masa kedepan turut menjadi

bagian dari kehidupan sehari-hari masyarakatnya. Penggunaan bahasa BugisMakassar mulai berkurang digunakan oleh masyarakat Kota Makassar. Aksara Lontara tidak lagi digunakan sehari-hari, dan hanya digunakan pada beberapa media tertentu seperti penanda jalan, atau di tempat wisata saja. Kemajuan teknologi transformasi dan informatika telah menggiring kecenderungan manusia ke satu dunia yang cenderung sama, dunia modern yang global (Yusring, B. 2018) sebagaimana tercerminkan pada situasi Kota Makassar sebagai kota metropolitan, dan pelabuhan modern, dengan masyarakat yang semakin heterogen mengurangi penggunaan bahasa Bugis-Makassar. Terdapat suatu ungkapan masyarakat Makassar "abbicara malayu tawwa" yang mengungkapkan sebuah kebanggaan masyarakat Makassar berbahasa Indonesia, dan meninggalkan bahasa BugisMakassar yang kalah prestis. Dengan berkurangnya penutur bahasa BugisMakassar, serta pengaplikasiannya dalam kehidupan sehari-hari, berkurang pula penggunaan aksara Lontara sebagai media tulisan dari bahasa tersebut.

Pelestarian terhadap Aksara Lontara terus dilakukan dengan melibatkan budayawan, lembaga pemerintaha, dan ahli bahasa daerah. Salah satu upaya 
pelestarian aksara Lontara adalah penyempurnaan tanda baca pada aksara ini, dan pengembangan dalam format Unicode sehingga dapat digunakan pada platform digital. Terlepas dari berbagai upaya tersebut, dengan tersedianya buku-buku lokal, dan pengadaan muatan lokal (mulok) pada kurikulum pembelajaran, saat ini pengguna aksara Lontara sebagai perantara bahasa Bugis-Makassar tetap minim.

Apabila melihat perjalanan sejarahnya, sudah sangat banyak aksara tradisional Sulawesi Selatan yang semakin ditinggalkan, terabaikan, dan tidak dilestarikan lagi saat ini seperti aksara Serang, aksara Jangang-jangang, dan aksara Bilang-bilang. Sebagai aksara yang menjadi tradisi tulisan dari bahasa Makassar yang digunakan oleh seluruh penjuru Sulawesi Selatan, aksara Lontara harus dapat dipertahankan dengan cara mengajarkan, dan meningkatkan peminatannya kepada generasi muda.

Aksara tradisional ini adalah warisan budaya yang menjadi identitas masyarakat Bugis-Makassar. Meski pada praktiknya budaya baca tulis masyarakat kota Makassar sering menyisihkan aksara Lontara dengan huruf Latin bukan berarti aksara ini dapat ditinggalkan begitu saja, sehingga perlu adanya edukasi yang sesuai untuk generasi muda. Berdasarkan pemaparan diatas, maka penulis akan merancang media pembelajaran kreatif untuk aksara Lontara dengan penerapannya pada media permainan.

\section{KESIMPULAN}

Masyarakat Indonesia dan luas, misalnya kebudayaan yang berkaitan dengan cara manusia hidup, adat istiadat dan tata krama. Yang heterogen juga adat istiadat dan kebiasaannya yang berbeda dan masih dipertahankan sampai saat ini, termasuk adat perkawinan.Masyarakat Bugis merupakan salah satu suku yang masih mempertahankan budaya dan adat istiadatnya di Indonesia. Suku Bugis yang tergolong ke dalam suku-suku Melayu Deutero, berasal dari kata To Ugi, yang berarti orang Bugis Penamaan "ugi" merujuk pada raja pertama kerajaan Cina yang terdapat di Pammana, Kabupaten Wajo saat ini, yaitu La Sattumpugi. Mereka menjuluki dirinya sebagai ToUgi atau orang-orang atau pengikut dari La Sattumpugi. Dalam perkembangannya, komunitas ini berkembang dan membentuk beberapa kerajaan lain. Masyarakat Bugis ini kemudian mengembangkan kebudayaan, bahasa, aksara Lontara dan pemerintahan mereka sendiri. Beberapa kerajaan Bugis klasik dan besar antara lain Luwu, Bone, Wajo, Soppeng, Suppa dan Sawitto (Kabupaten Pinrang), Sidenreng dan Rappang.

Hukum adat itu pada umumnya bercorak tradisional, artinya bersifat turun temurun, dari zaman nenek moyang sampai ke anak cucu sekarang keadaannya masih tetap berlaku dan dipertahankan oleh masyarakat yang bersangkutan. Misalnya dalam hukum kekerabatan adat orang batak yang menarik garis keturunan lelaki, sejak dulu sampai sekarang tetap saja mempertahankan hubungan kekerabatan yang disebut "dalihan na tolu" (bertungku tiga) yaitu hubungan antara 
marga hula-hula, dengan tubu (dongan sebutuha) dan bolu. Sehingga dengan adanya hubungan kekerabatan tersebut tidak terjadi perkawinan antara pria dan wanita yang satu keturunan (satu marga). Contoh corak tradisional di Lampung bahwa dalam hukum kewarisan berlaku sistem mayorat lelaki, artinya anak tertua lelaki menguasai seluruh harta peninggalan dengan kewajiban mengurus adik-adik nya sampai dewasa dan dapat berdiri sendiri. Harta peninggalan itu tetap tidak terbagibagi, merupakan milik keluarga bersama, yang kegunaannya untuk kepentingan anggota keluarga.

Kebudayaan Bugis dapat di telusuri dalam Lontara Kebudayaan Bugis merupakan kebudayaan tertua di Nusantara. Bugis memiliki nilai-nilai yang ingin disampaikan. Ada beberapa nilai-nilai budaya yang terkenal dalam masyarakat Bugis, yakni kejujuran (alempureng), kecendikiaan (amaccang), kepatutan (asitinajang), keteguhan (agettengeng), usaha (reso), dan malu (siri).

Saat ini, pemahaman sebagian besar masyarakat suku Bugis tentang pengertian mahar dan uang panai" masih banyak yang keliru. Masih ada segelintir orang yang menyamakan kedudukan mahar dan uang panai", namun adapula yang membedakannya. Dalam adat perkawinan Bugis, terdapat dua istilah yaitu sompa (mahar) dan uang panai"/doe" balanja (Bugis Makassar). Mahar adalah pemberian berupa uang atau harta dari pihak laki-laki kepada pihak perempuan sebagai syarat sahnya pernikahan menurut ajaran Islam. Sedangkan uang panai" adalah "uang antaran" yang harus diserahkan oleh pihak keluarga calon mempelai laki-laki kepada pihak keluarga calon mempelai perempuan untuk membiayai prosesi pesta pernikahan.

\section{REFERENSI}

Muh. Rafly Nurfaizy. Hukum Adat Bugis. Fakultas Syari'ah dan Hukum Universitas Allaudin Makassar. Makalah. 
Jumadi. Beberapa Aspek Negara Dan Hukum Dalam Sistem Adat Bugis. Jurnal Jurisprudentie Volume 5 Nomor 2 Desember 2018.

Ahmad Ubbe. Laporan AkhirPenelitian Hukum Tentang Perkembangan Hukum Adat Di Propinsi Sulawesi Selatan. Departemen Hukum Dan Hak Asasi Manusia Badan Pembinaan Hukum Nasional 2005.

https://dspace.uii.ac.id/bitstream/handle/123456789/6784/05.1\%20bab\%201.pdf?seque nce $=5 \&$ isAllowed $=y$

https://repository.usm.ac.id/files/skripsi/F11A/2015/F.111.15.0067/F.111.15.0067-04BAB-I-20200305012218.pdf

http://e-journal.uajy.ac.id/7139/2/HK110334.pdf 